\title{
SPORULATION OF ARBUSCULAR MYCORRHIZAL FUNGI USING TRIS-HCI BUFFER IN ADDITION TO NUTRIENT SOLUTIONS
}

\author{
Fábio Sérgio B. Silva; Adriana M. Yano-Melo; Joana Angélica C. Brandão; Leonor C. Maia* \\ Universidade Federal de Pernambuco, Centro de Ciências Biológicas, Departamento de Micologia, Recife, PE, Brasil \\ Submitted: September 10, 2004; Returned to authors for corrections: February 15, 2005; Approved: November 11, 2005
}

\begin{abstract}
The production of inoculum is one of the hindrances in the large scale application of arbuscular mycorrhizal fungi (AMF). The objective of this work was to evaluate the effect of nutrient solutions with or without Tris$\mathrm{HCl}$ buffer, on sporulation of AMF. The experiment was carried out in a greenhouse, using a substrate with sand and vermiculite (1:1 v/v). Fifty spores of Gigaspora margarita, Scutellospora heterogama, and Glomus etunicatum were inoculated in Sorghum vulgare (sorghum) or Panicum miliaceum (fodder millet). The substrate received the following nutrient solutions: Hoagland with $3 \mu \mathrm{M} \mathrm{P}(\mathrm{S} 1)$; Long Ashton II with $15.9 \mu \mathrm{M}$ P (S2) and Hoagland with $20 \mu \mathrm{M} \mathrm{P}(\mathrm{S} 3)$, with or without $50 \mathrm{mM}$ of Tris- $\mathrm{HCl}$ buffer (pH 6.5); the control treatment, consisting of a soil + sand + vermiculite $(2: 1: 1 \mathrm{v} / \mathrm{v})$ substrate was irrigated with deionized water. Ten weeks after the beginning of the experiment sporulation did not differ in treatments with sorghum. Panicum miliaceum promoted higher sporulation of the AMF than sorghum, and differences among treatments with nutrient solutions were observed. Production of spores of G. margarita and S. heterogama increased significantly after addition of buffer in S1 and S2, while that of G. etunicatum was improved when the substrate was irrigated with S1 + buffer and S3 solutions. Solution S1 + buffer benefited sporulation of the three fungi. However, as observed, each AMF, host, and substrate system should be studied separately for establishment of the most favorable conditions for inoculum production.
\end{abstract}

Key words: Glomus etunicatum, Gigaspora margarita, Scutellospora heterogama, inoculum production, nutrient solution

\section{INTRODUCTION}

Arbuscular mycorrhizal fungi (AMF) are obligate symbionts that need a compatible plant host to complete their life cycle and produce spores, the main source of propagules used for application in crop production. The AMF are not considered as host specific. However, some plants are more susceptible than others in relation to development of the symbiosis. Because of that, several studies have been carried out to determine the best combinations of AMF and host species, in order to increase spore production $(2,17,34)$.

Several systems for inoculum production of AMF have been developed, such as the aeroponic (18), hydroponic (16) and the monoxenic cultivation (32). Although these systems have the advantage of producing spores suitable for studies of ontogeny (40), ultrastructure (25), and molecular biology (30), in general they have the disadvantage of high cost of installation and maintenance (26). In some cases, reduction of the germination rate (18) and production of spores with smaller diameter (27) have been described, compared with the traditional methods, where the plant is cultivated in containers with different substrates. Gaur and Adholeya (11) obtained maximum production of AMF inoculum in sand, which may have allowed better soil aeration, drainage, oxygen supply and root growth than other substrates tested. Another advantage of pot culture in sand is the low maintenance cost (37).

*Corresponding Author. Mailing address: Departamento de Micologia - CCB - UFPE. 50670-420, Recife, PE, Brasil. Tel.: (+5581) 2126-8865, Fax: (+5581) 2126-8482. E-mail: leonorcmaia@yahoo.com.br 
The choice of the best method for inoculum production should consider the species of AMF, host combination, and soil characteristics (37). Among these factors, $\mathrm{pH}$ can affect directly the AMF, determining the occurrence of species (1) and the germination of spores (13). It also may indirectly affect the redox potential of the soil (7). Some species of AMF are found only in acid or alkaline soils and many do not grow when transferred to soils with a different $\mathrm{pH}$ (28). Bartolome-Esteban and Schenck (4) mentioned that $\mathrm{pH}$ does not directly affect the mycorrhizal association, but acts through interference in the activity of soil macro and micronutrients.

Due to the importance of $\mathrm{pH}$ for development of the mycorrhizal symbiosis, some organic buffers have been used in addition to nutrient solutions (26) and in the medium of the monoxenic culture $(8,21,27)$. Vilariño et al. (39) suggested that buffer stimulates growth of external hyphae of AMF, contributing to increase sporulation.

The objective of this work was to evaluate the effect of nutrient solutions with Tris-HCl buffer on sporulation of AMF.

\section{MATERIALS AND METHODS}

\section{Substrate and containers}

A substrate with sand ( $\mathrm{pH}$ 6.9) and vermiculite (medium granulation, $\mathrm{pH} 7.4$ ), in a 1:1 proportion (v:v), was used 15 days after sterilization in autoclave $\left(120^{\circ} \mathrm{C}\right.$ for $1 \mathrm{~h}$ at $\left.1 \mathrm{~atm}\right)$ for two consecutives days. For control treatment a mixture of soil: sand: vermiculite $(2: 1: 1, \mathrm{v} / \mathrm{v})$, similar to the natural substrate for AMF was used after sterilized as described. The soil was a Red Yellow Podzol, with $\mathrm{pH}$ 5.4 and $3 \mathrm{mg} \mathrm{dm}^{-3}$ of P, $1.4 ; 0.8 ; 0.12 ; 0.15$ and $0.20 \mathrm{cmol}$ $\mathrm{dm}^{-3}$ of $\mathrm{Ca}^{2+}, \mathrm{Mg}^{+2}, \mathrm{Na}^{+}, \mathrm{K}^{+}$, and $\mathrm{Al}^{3+}$ respectively, sterilized with methyl bromide ( $98 \%$ of methyl bromide and $2 \%$ of chloropicrine), and used after 15 days. The soil $\mathrm{pH}$ was adjusted to 6.0 with dolomitic limestone. Plastic pots $(8.5 \times 10 \mathrm{~cm})$ were filled with $300 \mathrm{~g}$ of substrate.

\section{Plant hosts}

Fifty seeds of sorghum (Sorghum vulgare L.) and fodder millet (Panicum miliaceum L.) were disinfected with sodium hypochlorite $(\mathrm{NaOH}) 0.5 \%$ for $15 \mathrm{~min}$, and germinated in each pot.

\section{AMF isolation and inoculation}

Spores of Gigaspora margarita Becker and Hall (UFPE 02), Scutellospora heterogama (Nicolson \& Gerdemann) Walker \& Sanders (UFPE 19) and Glomus etunicatum Becker \& Gerdemann (UFPE 06) from the Laboratório de Micorrizas da Universidade Federal de Pernambuco (UFPE) were maintained in association with fodder millet in a greenhouse and stored at $28^{\circ} \mathrm{C}$ for three months before being used. For each inoculation treatment, fifty spores were distributed in the pots immediately below the seeds of each host. The pots were maintained in the greenhouse with natural photoperiods, temperature range of $\mathrm{T}_{\min } .20 .87^{\circ} \mathrm{C} ; \mathrm{T}_{\max } \cdot 32.66^{\circ} \mathrm{C}$, and relative air humidity between $\mathrm{RH}_{\min } 44 \% ; \mathrm{RH}_{\max } 81.78 \%$.

\section{Nutrient solutions}

The following nutrient solutions were applied: $\mathrm{S} 1=$ Hoagland modified by Jarstfer and Sylvia (19), with $3 \mu \mathrm{M}$ P; $\mathrm{S} 1 \mathrm{~B}=$ Hoagland modified by Jarstfer and Sylvia (19) with $3 \mu \mathrm{M}$ P+buffer Tris-HCl, S2 = Long Ashton II modified by Liyanage (22), with $15.9 \mu \mathrm{M}$ P; S2B = Long Ashton II modified by Liyanage (22) with $15.9 \mu \mathrm{M} \mathrm{P}+$ Tris-HCl buffer, S3 = Hoagland modified by Millner and Kitt (26), with $20 \mu \mathrm{M} P$ and without the (2-[N-morpholino] ethanesulfonic acid) MES buffer and S3B $=$ Hoagland modified by Millner and Kitt (26), with $20 \mu \mathrm{M}$ $\mathrm{P}$ and without the (2-[N-morpholino] ethanesulfonic acid) MES buffer + Tris- $\mathrm{HCl}$ buffer.

The $\mathrm{pH}$ of buffer $(50 \mathrm{mM})$ was 6.5 and after adding it, the hydrogenionic concentration of solutions $\mathrm{S} 1, \mathrm{~S} 2$ and $\mathrm{S} 3$ changed respectively from 4.95 to $6.32 ; 5.4$ to $5.83 ; 4.78$ to 6.40 . The pots were irrigated every other day with the nutrient solutions and once a week with distilled deionized water, to avoid accumulation of salts. The control treatment was irrigated only with distilled deionized water (Table 1).

Table 1. Nutrient solutions: S1- Hoagland modified by Jarstfer and Sylvia (19), S2- Long Ashton II modified by Liyanage (22), and S3- Hoagland modified by Millner and Kitt (26)

\begin{tabular}{|c|c|c|c|}
\hline \multirow{2}{*}{$\begin{array}{c}\text { Nutrient } \\
\text { Composition }\end{array}$} & \multicolumn{3}{|c|}{ Final concentration / L } \\
\hline & S1 & $\mathrm{S} 2$ & S3 \\
\hline & \multicolumn{3}{|c|}{ Macronutrients } \\
\hline $\mathrm{KNO}_{3}$ & $1.5 .10^{-3} \mathrm{M}$ & $0.4 .10^{-3} \mathrm{M}$ & $2.5 .10^{-3} \mathrm{M}$ \\
\hline $\mathrm{Ca}\left(\mathrm{NO}_{3}\right)_{2} \cdot 4 \mathrm{H}_{2} \mathrm{O}$ & $1.5 .10^{-3} \mathrm{M}$ & $0.27 \cdot 10^{-3} \mathrm{M}$ & $2.5 \cdot 10^{-3} \mathrm{M}$ \\
\hline $\mathrm{MgSO}_{4} \cdot 7 \mathrm{H}_{2} \mathrm{O}$ & $0.3 \cdot 10^{-3} \mathrm{M}$ & $0.15 \cdot 10^{-3} \mathrm{M}$ & 1. $10^{-3} \mathrm{M}$ \\
\hline $\mathrm{KH}_{2} \mathrm{PO}_{4}$ & $3.10^{-6} \mathrm{M}$ & - & $20.10^{-6} \mathrm{M}$ \\
\hline $\mathrm{NaH}_{2} \mathrm{PO}_{4} \cdot \mathrm{H}_{2} \mathrm{O}$ & - & 15.9. $10^{-6} \mathrm{M}$ & - \\
\hline FeNa EDTA & $45.10^{-6} \mathrm{M}$ & 4.9. $10^{-6} \mathrm{M}$ & $50.10^{-6} \mathrm{M}$ \\
\hline \multirow[t]{2}{*}{$\mathrm{NaCl}$} & $30.10^{-6} \mathrm{M}$ & 9.9. $10^{-6} \mathrm{M}$ & - \\
\hline & \multicolumn{3}{|c|}{ Micronutrients } \\
\hline $\mathrm{MnSO}_{4} \cdot \mathrm{H}_{2} \mathrm{O}$ & - & 1.3. $10^{-6} \mathrm{M}$ & - \\
\hline $\mathrm{ZnSO}_{4} .7 \mathrm{H}_{2} \mathrm{O}$ & $0.7 \cdot 10^{-6} \mathrm{M}$ & $0.1 .10^{-6} \mathrm{M}$ & 1. $10^{-6} \mathrm{M}$ \\
\hline $\mathrm{CuSO}_{4} .5 \mathrm{H}_{2} \mathrm{O}$ & $0.3 \cdot 10^{-6} \mathrm{M}$ & $0.1 .10^{-6} \mathrm{M}$ & $0.5 \cdot 10^{-6} \mathrm{M}$ \\
\hline $\mathrm{NiSO}_{4} \cdot 6 \mathrm{H}_{2} \mathrm{O}$ & - & - & $0.2 \cdot 10^{-6} \mathrm{M}$ \\
\hline $\mathrm{MnCl}_{2} \cdot 4 \mathrm{H}_{2} \mathrm{O}$ & $9.5 .10^{-6} \mathrm{M}$ & - & 2. $10^{-6} \mathrm{M}$ \\
\hline $\mathrm{Na}_{2} \mathrm{MoO}_{4} \cdot 2 \mathrm{H}_{2} \mathrm{O}$ & $0.066 .10^{-6} \mathrm{M}$ & - & $0.2 \cdot 10^{-6} \mathrm{M}$ \\
\hline $\mathrm{HCl} 3 \mathrm{~N}$ & - & - & $25.10^{-6} \mathrm{M}$ \\
\hline $\mathrm{H}_{3} \mathrm{BO}_{3}$ & $46.2 \cdot 10^{-6} \mathrm{M}$ & 5. $10^{-6} \mathrm{M}$ & $10.10^{-6} \mathrm{M}$ \\
\hline
\end{tabular}




\section{Experimental design}

Two experiments were performed in a completely randomized design, one with $P$. miliaceum, the other using $S$. vulgare, in order to evaluate the effect of nutrient solution (with or without buffer) on sporulation of AMF. Each experiment was in factorial of 7x3: 6 nutrient solutions (S1, S1B, S2, S2B, S3 and S3B) + 1 control (without nutrient solution) x 3 AMF isolates $(G$. margarita, G. etunicatum and S. heterogama) in 3 replicates, in a total of 63 experimental parcels for each host.

\section{Evaluation and statistical analysis}

Seventy days after the beginning of the experiment, spores of AMF were extracted from the substrates, by wet sieving and decanting (12) and water and sucrose centrifugation (20), placed in Petri dishes and counted in a stereomicroscope (40x).

For variance analysis the factors: 1) AMF and 2) Nutrient solution and interaction between them, were employed. Data were transformed in $\sqrt{x}+1$ and media compared by the Tukey test at 5\% probability, using the Statistica (33) and Sanest (41) programs.

\section{RESULTS}

Higher sporulation of AMF was observed in the treatment with $P$. miliaceum where in absolute numbers density of spores varied from $3.7 \mathrm{~g}^{-1}$ substrate (S. heterogama) to $152.8 \mathrm{~g}^{-1}$ substrate (G. etunicatum); in the rhizosphere of $S$. vulgare sporulation was from $0.03 \mathrm{~g}^{-1}$ substrate to $1.54 \mathrm{~g}^{-1}$ substrate considering $G$. etunicatum. Production of spores did not differ in the experiment with $S$. vulgare using the nutrient solutions (Table 2). However, comparing among the fungi, the sporulation differed in the treatments control, S3 and S3B. Gigaspora margarita produced more spores in media with these solutions, differing from $S$. heterogama in S3 and from G. etunicatum in S3B. In the control

Table 2. Production of spores ( $\mathrm{n}^{\mathrm{o}} \mathrm{g}^{-1}$ substrate) of Gigaspora margarita, Glomus etunicatum and Scutellospora heterogama, after 70 days associated to fodder millet (Panicum miliaceum) and sorghum (Sorghum vulgare), in substrates irrigated or not with nutrient solution and supplemented or not with Tris-HCl buffer ( $\mathrm{pH} 6.5)$.

\begin{tabular}{|c|c|c|c|c|c|c|c|}
\hline \multirow[t]{2}{*}{ Fungi } & \multicolumn{7}{|c|}{$\begin{array}{c}\text { Nutrient Solutions }^{1} \\
\text { P. miliaceum } \\
\end{array}$} \\
\hline & S1 & S1B & S2 & S2B & S3 & S3B & Control \\
\hline G. margarita & 13.8abAB & $43.6 \mathrm{aB}$ & $4.7 \mathrm{bA}$ & 29.9abA & 21.3abB & $30.3 \mathrm{aB}$ & 19.1abA \\
\hline G. etunicatum & 31.2bA & $108.0 \mathrm{aA}$ & $18.6 \mathrm{bA}$ & $36.8 \mathrm{bA}$ & $152.8 \mathrm{aA}$ & $94.7 \mathrm{aA}$ & $27.2 \mathrm{bA}$ \\
\hline S. heterogama & $5.4 \mathrm{bB}$ & $44.5 \mathrm{aB}$ & $4.8 \mathrm{bA}$ & $32.5 \mathrm{aA}$ & $3.7 \mathrm{bB}$ & $20.5 \mathrm{abB}$ & 20.0abA \\
\hline Factors & D.F. & S.S. & M.S. & F value & Prob.>F & & \\
\hline $\operatorname{AMF}(F)$ & 2 & 139.92170 & 69.960850 & 41.8092 & 0.00001 & & \\
\hline Solutions (S) & 6 & 139.84303 & 23.307173 & 13.9425 & 0.00001 & & \\
\hline $\mathrm{FxS}$ & 12 & 115.18231 & 9.598526 & 5.7377 & 0.00005 & & \\
\hline Residue & 42 & 70.58384 & 1.680567 & & & & \\
\hline \multirow[t]{3}{*}{ CV\% } & 23.83 & & & & & & \\
\hline & \multicolumn{7}{|c|}{ S. vulgare } \\
\hline & S1 & S1B & S2 & S2B & S3 & S3B & Control \\
\hline G. margarita & $0.63 \mathrm{aA}$ & $0.04 \mathrm{aA}$ & $0.31 \mathrm{aA}$ & $0.08 \mathrm{aA}$ & $0.49 \mathrm{aA}$ & $0.44 \mathrm{aA}$ & $0.44 \mathrm{aB}$ \\
\hline G. etunicatum & $0.22 \mathrm{bA}$ & $0.04 \mathrm{bA}$ & $0.08 \mathrm{bA}$ & $0.03 \mathrm{bA}$ & $0.22 \mathrm{bAB}$ & $0.10 \mathrm{bB}$ & $1.54 \mathrm{aA}$ \\
\hline S. heterogama & $0.24 \mathrm{aA}$ & $0.08 \mathrm{aA}$ & $0.13 \mathrm{aA}$ & $0.09 \mathrm{aA}$ & $0.07 \mathrm{aAB}$ & $0.10 \mathrm{aAB}$ & $0.28 \mathrm{aB}$ \\
\hline Factors & D.F. & S.S. & M.S. & $F$ value & Prob.> & & \\
\hline $\operatorname{AMF}(\mathrm{F})$ & 2 & 16.973223 & 8.486618 & 7.4479 & 0.00211 & & \\
\hline Solutions (S) & 6 & 90.717230 & 15.119538 & 13.0574 & 0.00001 & & \\
\hline $\mathrm{FxS}$ & 12 & 63.983180 & 5.3319317 & 4.7649 & 0.00020 & & \\
\hline Residue & 42 & 48.157387 & 1.1466045 & & & & \\
\hline CV\% & 32.12 & & & & & & \\
\hline
\end{tabular}

Means followed by the same small letter (line) and capital letter (column) does not differ $(\mathrm{P}<0.05) .{ }^{1} \mathrm{~S} 1=$ Hoagland modified by Jarstfer and Sylvia (19), S1B= Hoagland modified by Jarstfer and Sylvia (19)+buffer Tris-HCl, S2= Long Ashton II modified by Liyanage (22), S2B= Long Ashton II modified by Liyanage (22) + Tris-HCl buffer, S3= Hoagland modified by Millner and Kitt (26) and S3B= Hoagland modified by Millner and Kitt (26) + Tris-HCl buffer; Control: soil+sand+vermiculite. 
treatment, G. etunicatum produced higher amount of spores, differing from the other fungi (Table 2). In the experiment with $P$. miliaceum, statistical difference among sporulation of the AMF was observed in the treatments $\mathrm{S} 1, \mathrm{~S} 1 \mathrm{~B}, \mathrm{~S} 3$ and $\mathrm{S} 3 \mathrm{~B}$, with $G$. etunicatum producing the highest amount of spores.

Higher sporulation of $G$. etunicatum in P. miliaceum was found in the treatments S3 (increment of 92,425\%), S3B and $\mathrm{S} 1 \mathrm{~B}$, and all of them differed from the control. The production of spores of $S$. heterogama increased with addition of buffer in substrates receiving nutrient solutions S1 and S2 (Table 2), when compared with samples without buffer, although not differing of the control, while sporulation of G. margarita increased with addition of Tris- $\mathrm{HCl}$, but did not differ from treatments with solutions free of buffer. Thus, presence of buffer significantly stimulated sporulation $(\mathrm{p}<0.001)$, promoting increase of about eight and six times, respectively, in relation to the S1 and S2 solutions for S. heterogama, and increase of five times for $G$. margarita maintained in substrate receiving the S2B solution. In this case, however, the average of spore production did not significantly differ from that of the treatment using solution S2 (without buffer). Although the use of buffer in all solutions had promoted higher sporulation than the treatments buffer free, the results did not significantly differ (at the level of 5\%) from the control (Table 2), with exception of $G$. etunicatum. Solution S2 (Long Ashton II without buffer) did not stimulate the sporulation of the AMF, which was similar to that produced by the control.

\section{DISCUSSION}

The high sporulation of the AMF with fodder millet, in this experiment, was similar to the results obtained by Bagyaraj and Manjunath (2) using Panicum maximum Jacq. and Glomus fasciculatum (Thaxter) Gerd. \& Trappe emend Walker \& Koske. The authors observed that the association of this fungus with $P$. maximum produced about 730 spores $50 \mathrm{~g}^{-1}$ of soil, after 75 days, while with sorghum the sporulation was $50 \%$ lower (346 spores $50 \mathrm{~g}^{-1}$ of soil). Using the same fungus associated with Sorghum vulgare var. sudanense (Piper) Hitch., Hetrick and Bloom (17) observed higher production of spores of $G$. fasciculatum than that obtained with other plant species; however the experiment was concluded in approximately 120 days. It is possible that the duration of the experiment positively affected the sporulation, as also observed by Luedders et al. (24). Struble and Skipper (34) observed an increase in the sporulation of several species of AMF associated with sorghum with the increase of culture duration. Thus, the low results on sporulation of the AMF associated with sorghum in this study might be related to the short duration of the experiment (70 days).

The production of hormones by the host is not equal throughout its phenological cycle, and this can affect sporulation $(35,36)$, establishment, and effectiveness of the mycorrhizal symbiosis (3). When the host is in the flowering stage, high consumption of energy is required, which may decrease the flow of carbohydrates to the AMF (5). This could be a sign to stimulate the production of spores as a strategy for survival. Thus, the flowering of fodder millet, which occurred 60 days after the beginning of the experiment, may have contributed to stimulate sporulation of the AMF in this host. The same did not occur with sorghum, which was in vegetative growth through the 70 days of the experiment; in this case, production of spores was not stimulated.

Although in AMF host specificity seems not to exist (15), the difference in the sporulation of the species associated with fodder millet vs. sorghum, reinforces Sanders and Fitter's (29) hypothesis of the existence of an "optimum" host-AMF combination, as well as differences in the cycles and strategies of life of the AMF species (6). It has been suggested that AMF differ in growth, sporulation and establishment of the symbiosis as a function of the host, due to differential perception of signs emitted by the root $(14,17)$. Abe et al. (1) considered the possibility of the specificity between Elymus mollis Trin. (Gramineae) and species of Glomus to justify the predominance of Glomus species in the rhizosphere of this plant.

Hoagland's solution, modified by Jarstfer and Sylvia (19) and supplemented with Tris $\mathrm{HCl}$ buffer (S1B) promoted higher sporulation of $G$. etunicatum and S. heterogama than the treatment without buffer supply. One of the factors contributing to this result was probably the low concentration of $\mathrm{P}$ in this nutrient solution $(3 \mu \mathrm{M})$. High concentration of $\mathrm{P}$ can reduce hyphal growth (23), as well as colonization and sporulation of AMF (10), while the reduction can improve spore production $(9,38)$. On the other side, high sporulation of G. etunicatum was obtained in substrate irrigated with S1B or with S3, what indicates possible plasticity of this isolate in relation to wide values of $\mathrm{pH}$ and $\mathrm{P}$ concentration in the nutrient solution.

An increase in spore density of AMF when the buffer was added to the solutions probably occurred due to the maintenance of the $\mathrm{pH}$ in the substrate. Vilariño et al. (39) used Tris- $\mathrm{HCl}$ and MES buffers for sporulation of Glomus intraradices Schenck \& Smith; $\mathrm{pH}$ was reduced in both substrates, but only the MES buffer promoted increase of extraradical hyphae and sporulation of the AMF. The authors concluded that this occurred due to the activity of soil microorganisms stimulated by MES buffer, possibly through liberation of sulphur in this compound. On the other hand, Douds Jr. (8) observed improved hyphal growth of Glomus mosseae (Nicolson \& Gerd.) Gerd. \& Trappe in a medium supplemented with $10 \mathrm{mM}$ Tris, in comparison to the addition of MES buffer. Our results showed that the sporulation of the AMF in the control treatment was in general similar to that obtained in the treatment using solutions without buffer, what indicates the importance of the buffer capacity of the soil in the control mixture. Sporulation of G. etunicatum in the treatments with solutions 
S1B, S3 and S3B differed from the control. However, effect of addition of buffer, among the solutions, was observed only in the $\mathrm{S} 1$ treatment.

The results of Millner and Kitt (26) were similar to those obtained in this work with G. margarita and G. etunicatum; however, the amount of the initial inoculum used by these authors was, respectively, seven and forty times higher than that employed here, indicating that it is possible to obtain high sporulation with a low initial amount of inoculum.

Although the hosts were in different developmental stages at the 85th day, it was shown that each one had a singular effect on sporulation, confirming previous studies (31) that indicate a host effect on production of spores of AMF. Thus, in a same period of time, fodder millet was a better host than sorghum, promoting sporulation of the AMF.

The solutions S1 and S2 receiving buffer improved the sporulation mainly of $S$. heterogama, but it is not possible to say if this was due to $\mathrm{pH}$ or to the own organic compounds present in the solutions.

In conclusion, the use of buffer enhanced sporulation of the AMF, especially that of $S$. heterogama e $G$. etunicatum. Studies involving a new cycle of multiplication of AMF in sorghum and other hosts, can also confirm or not the decisive role of phenologic stages in the sporulation process. In the same way, studies regarding the effect of Tris- $\mathrm{HCl}$ buffer on germination, hyphal growth and mycorrhizal colonization should be made so that the behavior of other AMF species in relation to buffer supply can be understood.

\section{ACKNOWLEDGEMENTS}

The authors are gratefull to the Conselho Nacional de Desenvolvimento Científico e Tecnológico (CNPq) for financial support and fellowships: PIBIC-UFPE (F.S.B. Silva and J.A.C. Brandão); DCR (A.M. Yano-Melo) and Research (L.C. Maia); to Dr. James Kimbrough, for correcting the English version, Drs. Aldo Vilar Trindade, Paulo Henrique Grazziote, Geraldo Milanez, Everardo Sampaio, and the anonymous reviewers for criticism and suggestions.

\section{RESUMO}

\section{Esporulação de fungos micorrízicos arbusculares usando solução nutritiva adicionada de tampão Tris HCl}

A produção de inóculo é um dos entraves na aplicação de fungos micorrízicos arbusculares (FMA) em larga escala. O objetivo deste trabalho foi avaliar o efeito de soluções nutritivas associadas a tampão Tris-HCl sobre a esporulação dos FMA.. Foram conduzidos dois experimentos em casa de vegetação, um para cada hospedeiro, painço (Panicum miliaceum) e sorgo
(Sorghum vulgare), usando como substrato areia:vermiculita $(1: 1 \mathrm{v} / \mathrm{v})$, onde foram aplicados cinqüenta esporos de Gigaspora margarita, Scutellospora heterogama e Glomus etunicatum. O substrato foi irrigado com as seguintes soluções nutritivas: Hoagland com $3 \mu \mathrm{MP}$ (S1), Long Ashton II com 15,9 $\mu \mathrm{MP}$ (S2) e Hoagland com $20 \mu \mathrm{M}$ P (S3), com ou sem 50 mM de tampão Tris-HCl ( $\mathrm{pH} 6,5)$; o tratamento controle, que consistiu de solo: areia:vermiculita (2:1:1 v/v) recebeu água deionizada. Após 10 semanas não houve diferença na esporulação, nos tratamentos com sorgo, exceto para G. etunicatum. Porém, no experimento com painço os tratamentos com solução nutritiva diferiram significativamente. A esporulação de S. heterogama aumentou após adição do tampão nas soluções $\mathrm{S} 1$ e $\mathrm{S} 2$, enquanto a de $G$. etunicatum foi incrementada no substrato irrigado com $\mathrm{S} 1+$ tampão e $S 3$, independente da presença do tampão. A produção de esporos de G. margarita foi maior nas soluções S1 e S3, ambas com tampão, porém diferenças significativas foram observadas somente em relação à solução $\mathrm{S} 2$, sem tampão. A utilização de soluções nutritivas e a adição de tampão podem contribuir para o aumento da esporulação de FMA; porém, como demonstrado, cada sistema substrato, FMA e hospedeiro deve ser avaliado separadamente, para estabelecimento das condições mais favoráveis para produção de inóculo em larga escala.

Palavras-chave: Glomus etunicatum, Gigaspora margarita, Scutellospora heterogama, produção de inóculo, solução nutritiva

\section{REFERENCES}

1. Abe, J.P.; Masuhara, G.; Katsuya, K. Vesicular-arbuscular mycorrhizal fungi in coastal dune plant communities. I. Spore formation of Glomus spp. predominates under a patch of Elymus mollis. Mycoscience, 35, 233-238, 1994.

2. Bagyaraj, D.J.; Manjunath, A. Selection of a suitable host for mass production of VA mycorrhizal inoculum. Plant Soil, 55, 495-498, 1980

3. Barea, J.M.; Azcón-aguilar, C. Production of plant growth-regulating substances by the vesicular-arbuscular mycorrhizal fungus Glomus mosseae. Appl. Environ. Microbiol., 43, 810-813, 1982.

4. Bartolome-Esteban, H.; Schenck, N.C. Spore germination and hyphal growth of arbuscular mycorrhizal fungi in relation to soil aluminum saturation. Mycologia, 86, 217-226, 1994.

5. Bethlenfalvay, G.J.; Pacovsky, R.S.; Brown, M.S.; Fuller, G. Mycotrophic growth and mutualistic develeopment of host plant and fungal endophyte in an endomycorrhizal symbiosis. Plant Soil, 68, 43-54, 1982.

6. Boddington, C.L.; Dodd, J.C. Evidence that differences in phosphate metabolism in mycorrhizas formed by species of Glomus and Gigaspora might be related to their life-cycle strategies. New Phytol. 142, 531-538, 1999.

7. Carlile, M.J.; Watinkson, S.C. The Fungi. London, 1994, 482p.

8. Douds Jr, D.D. A procedure for the establishment of Glomus mosseae in dual culture with Ri- T- DNA transformed carrot roots. Mycorrhiza, 7, 57-61, 1997.

9. Douds Jr, D.D.; Schenck, N.C. Relationship of colonization and sporulation by VA mycorrhizal fungi to plant nutrient and carbohydrate contents. New Phytol., 116, 621-627, 1990. 
10. Furlan, V.; Bernier-Cardon, M. Effects of N, P and K on formation of vesicular-arbuscular mycorrhizae, growth and mineral content of onion. Plant Soil, 113, 167-174, 1989

11. Gaur, A.; Adholeya, A. Effects of particle size of soilless substrates upon AM fungus inoculum production. Mycorrhiza, 10, 43-48, 2000.

12. Gerdemann, J.W.; Nicolson, T.H. Spores of mycorrhizal Endogone species extracted from soil by wet sieving and decanting. Trans. Br. Mycol. Soc., 46, 235-244, 1963.

13. Green, N.E.; Graham, S.O.; Schenck, N.C. The influence of pH on germination of vesicular-arbuscular mycorrhizal spores. Mycologia, 68, 929-933, 1976.

14. Giovannetti, M.; Sbrana, C.; Logi, C. Early processes involved in host recognition by arbuscular mycorrhizal fungi. New Phytol., 127, 703-709, 1994

15. Harley, J.L.; Smith, S.E. Mycorrhizal Symbiosis. London, 1983, 483 p.

16. Hawkins, H.J.; George, E. Hidroponic culture of the mycorrhizal fungus Glomus mosseae with Linum usitatissmum L., Sorghum bicolor L. and Triticum aestivum L. Plant Soil, 196, 143-149, 1997.

17. Hetrick, B.A.D.; Bloom, J. The influence of host plant on production and colonization ability of vesicular arbuscular mycorrhizal spores. Mycologia, 78, 32-36, 1986.

18. Hung, L.L.L.; Sylvia, D.M. Production of vesicular arbuscular mycorrhizal fungus inoculum in aeroponic culture. Appl. Environ. Microbiol., 154, 353-357, 1988.

19. Jarstfer, A.G.; Sylvia, D.M. Inoculum production and inoculation strategies for vesicular arbuscular mycorrhizal fungi. In: Blaine Meeting Jr., F. (ed.). Soil Microbial Ecology. Application in Agricultural and Environmental Management. Marcel Dekker, New York, 1992. p. 349-369.

20. Jenkins, W.R. A rapid centrifugal-flotation technique for separating nematodes from soil. Pl. Dis. Rep., 48, 692, 1964.

21. Karandashov, V.; Kurozovkina, I.; Hawkin, H.J.; George, E. Growth and sporulation of the arbuscular mycorrhizal fungus G. caledonium in dual culture with transformed carrot roots. Mycorrhiza, 10, 2328,2000 .

22. Liyanage, H.D. Effects of phosphorus nutrition and host species on root colonization and sporulation by vesicular-arbuscular (VA) mycorrhizal fungi in sand-vermiculite medium. Gainesville, 1989. (M.Sc. Thesis, University of Florida).

23. Louis, I.; Lim, G. Observations on in vitro sporulation of Glomus clarum. Trans. Br. Mycol. Soc., 91, 698-699, 1988.

24. Luedders, V.D.; Carling, D.E.; Brown, M.F. Effect of soybean plant growth on spore production by Glomus mosseae. Plant Soil, 53, 393-397, 1979.

25. Maia, L.C.; Kimbrough, J.W. Ultrastructural studies of spores and hypha of a Glomus species. Int. J. Pl. Sci., 159, 581-589, 1998.
26. Millner, P.; Kitt, D.G. The Beltsville method for soiless production of vesicular arbuscular fungi. Mycorrhiza, 2, 9-15, 1992.

27. Pawlowska, T.E.; Douds, D.D.; Charvat, I. In vitro propagation and life cycle of the arbuscular mycorrizal fungus Glomus etunicatum. Mycol. Res., 103, 1549-1556. 1999.

28. Robson, A.D.; Abbott, L.K. The effect of soil acidity on microbial activity in soils. In: Robson A.D. (ed.). Soil Acidity and Plant Growth. Academic Press, Sydney, 1989. p. 139-165.

29. Sanders, I.R.; Fitter, A.H. Evidence for differential responses between host-fungus combinations of vesicular-arbuscular mycorrhizas from a grassland. Mycol. Res., 96, 415-419, 1992.

30. Sawaki, H.; Saito, M. Expressed genes in the extraradical hyphae of an arbuscular mycorrhizal fungus, Glomus intraradices, in the symbiotic phase. FEMS Microbiol. Lett., 195, 109-113, 2001.

31. Simpson, D.; Daft. M.J. Spore production and mycorrhizal development in various tropical crop hosts infected with Glomus clarum. Plant Soil, 121, 171-178, 1990

32. St-Arnaud, M.; Hamel, C.; Vimard, B.; Caron, M.; Fortin, J.A. Enhanced hyphal growth and spore production of the arbuscular mycorrhizal fungus Glomus intraradices in an in vitro system in the absence of the host roots. Mycol. Res., 100, 328-332, 1996.

33. Statsoft. Statistica for Windows. Tulsa, USA. 1997.

34. Struble, J.E.; Skipper, H.D. Vesicular arbuscular mycorrhizal fungal spore production as influenced by plant species. Plant Soil, 109, 277-280, 1988

35. Suttton, J.C. Development of vesicular-arbuscular mycorrhizae in crop plants. Can. J. Bot., 51, 2487-2493, 1973.

36. Sutton, J.C.; Barron, G.L. Population dynamics of Endogone spores in soil. Can. J. Bot., 50, 1909-1914, 1972.

37. Sylvia, D.M.; Jarstfer, A.G. Production of inoculum and inoculation with arbuscular mycorrhizal fungi. In: Robson, A.P.; Abbott, L.K.; Malajczek, N. (eds.). Management of Mycorrhizas in Agriculture, Horticulture and Forestry. Kluver Academic Press, The Netherlands, 1994. p. 231-238.

38. Sylvia, D.M.; Schenck, N.C. Application of superphosphate to mycorrhizal plants stimulates sporulation of phosphorus tolerant vesicular-arbuscular mycorrhizal fungi. New Phytol., 95, 655-661, 1983.

39. Vilariño, A.; Frey, B.; Shüepp, H. MES [2-(N- morpholine)- ethane sulphonic acid] buffer promotes the growth of external hyphae of the arbuscular mycorrhizal fungus Glomus intraradices in an alkaline sand. Biol. Fert. Soils, 25, 79-81, 1997.

40. Wu, C.G.; Liu, Y.S.; Hung, L.L. Spore development of Entrophospora kentinensis in an aeroponic system. Mycologia, 87, 582-587, 1995.

41. Zonta, E.P.; Machado, A.A.; Silveira Jr., P. Sistema de análise estatística para microcomputadores - SANEST. Pelotas: UFPel, 1984. 80p. 